\title{
Fluoride Removal from Industrial Effluents by Combining Precipitation and Electrocoagulation Processes
}

\begin{abstract}
MONICA IHOS*, MIHAELA DRAGALINA, IULIANA IORDACHE, DORIAN NEIDONI
National Research and Development Institute for Industrial Ecology ECOIND, Timisoara Subsidiary, Street Bujorilor no. 115, code 300431, Timisoara, Romania

The aim of this study was the removal of fluoride from a fluoride-rich industrial wastewater by combining two processes, precipitation with a magnesium salt and electrocoagulation. The sacrificial anode was made of Al and the applied current densities were of 100,200 and $300 \mathrm{~A} / \mathrm{m}^{2}$, respectively. The experiments were conducted at pH of 5.2, 6.2 and 7.2, respectively, and the electrolysis time was of 15, 30, 45 and $60 \mathrm{~min}$, respectively. $0.01 \mathrm{M} \mathrm{NaCl}$ was supporting electrolyte. The best results were obtained at $\mathrm{pH}$ of $6.2,200 \mathrm{~A} / \mathrm{m}^{2}$ and 45 minutes of electrolysis when the specific energy consumption was of $5.6 \mathrm{kWh} / \mathrm{m}^{3}$.
\end{abstract}

Keywords: electrocoagulation, fluoride, industrial effluents, removal

The discharge of industrial effluents containing high concentration of fluoride in the environment can cause serious health problems by contaminating the surface and ground waters. The fluoride is an essential element in a narrow range of concentration, between 0.5 and $1 \mathrm{mg} / \mathrm{L}$, but it is harmful for the human health when exceeds 1.5 $\mathrm{mg} / \mathrm{L}$.

Industrial effluents containing high concentration of fluoride are originated from many chemical processes, particularly those involved in the semiconductor, solar cell, plating, and metal manufacturing industries. Fluoride concentration from these industries can range from hundreds to thousands ppm [1].

Therefore, effluents containing fluoride are to be treated in order to reduce their concentration to limit allowed by regulations in use before their discharge into sewerage systems or surface waters. Thus, processes as precipitation [2-4], adsorption [5-11] that can be used also to remove metals from wastewaters [12-15], precipitation and adsorption [16], removal as fluorapatite crystals [1] and coagulation [17]. Itis important to notice that wastewaters containing fluoride require polishing after precipitation by other processes like adsorption or electrochemical processes.

Electroflotation [18] and electrocoagulation [19] are expected to be important techniques in polishing industrial effluents containing fluoride because of advantages of electrochemical methods like versatility, energy efficiency, suitable for automation, environmental compatibility and cost effectiveness that match excellent for wastewater treatment purposes. Thus, the electrochemical methods have been applied not only to remove inorganic pollutants from wastewaters, but also organics ones [20].

This study aimed to remove the fluoride from a simulated high fluoride concentration industrial effluent by precipitation followed by electrocoagulation as polishing step. Our findings indicated that the combination of these processes is promising regarding the treatment of fluoriderich industrial wastewaters.

\section{Experimental part}

All reagents were of analytical grade and the solutions were prepared with distilled water. A simulated industrial effluent of $1000 \mathrm{ppm}$ fluoride was prepared. The NaF was purchased from Sigma Aldrich.
In the first step fluoride was removed by precipitation. For this purpose, $\mathrm{MgSO}_{4} \cdot 7 \mathrm{H}_{2} \mathrm{O}$ (Sigma Aldrich) was added to the simulated effluent under stirring and in molar ratio $\mathrm{Mg}: \mathrm{F}$ of 1:2. The $\mathrm{pH}$ was adjusted to 9.6 with $\mathrm{NaOH}$ (Sigma Aldrich) and the stirring was kept during $30 \mathrm{~min}$. When the stirring time ended, the solution was allowed to stand for precipitation completion and then low-porosity paper was used to separate the precipitate. The solution thus obtained was named EFL and it was of $222 \mathrm{ppm}$ fluoride.

In the second step, the fluoride removal was carried out by electrocoagulation from EFL. The $\mathrm{pH}$ was adjusted to $5.2,6.2$ and 7.2 , respectively with $\mathrm{HCl}$ (Merck Millipore). The electrocoagulation experiments were carried out in a Plexiglas cell with horizontal electrodes. The sacrificial anode of $5.6 \times 14 \mathrm{~cm}$ was made on aluminium and the cathode was a wire mesh grid made of $3 \mathrm{~mm}$ diameter stainless steel wires. The distance between the electrodes was $5 \mathrm{~mm}$.

Volumes of $500 \mathrm{ml} \mathrm{EFL}$ were introduced in the cell, and the applied current densities were 100,200 and $300 \mathrm{~A} / \mathrm{m}^{2}$. Electrolysis duration was 60 minutes and samples were taken at every $15 \mathrm{~min}$. The supporting electrolyte was 0.01 $\mathrm{M} \mathrm{NaCl}$. NaCl was purchased from Chem-Lab.

The fluoride concentration was determined by using a Thermo Scientific Orion fluoride ion selective electrode (range: from $0.02 \mathrm{ppm}$ to saturate). TISAB II solution was used as a buffer to maintain the $\mathrm{pH}$ and background ion concentrations. The samples that underwent analysis were filtered on microfilters of $0.45 \mu \mathrm{m}$.

\section{Results and discussions}

In tables 1-3 are presented the results of carried out experiments. It can be noticed that regardless of $\mathrm{pH}$ initial values and applied current densities, as the electrolysis time increased, the increase of fluoride removal efficiency by electrocoagulation was recorded. However, exceptions must be mentioned. Thus, at $200 \mathrm{~A} / \mathrm{m}^{2}$ and initial $\mathrm{pH}$ of 6.2 and 7.2, the removal fluoride lowered at electrolysis time of $60 \mathrm{~min}$ versus $45 \mathrm{~min}$. At $300 \mathrm{~A} / \mathrm{m}^{2}$ this behaviour was observed for at all three initial $\mathrm{pH}$ values.

At initial pH of 5.2, at any electrolysis time was recorded the increase of fluoride removal efficiency as the applied current density increased, but exceptions occurred at initial $\mathrm{pH}$ of 6.2 and electrolysis time of 45 and $60 \mathrm{~min}$, respectively, when the fluoride removal efficiency was slightly higher at $200 \mathrm{~A} / \mathrm{m}^{2}$ versus $300 \mathrm{~A} / \mathrm{m}^{2}$. When the initial 
Table 1

WORKING CONDITIONS, FLUORIDE RESIDUAL CONCENTRATION FOR EFL AND FLUORIDE REMOVAL EFFICIENCY

\begin{tabular}{|c|c|c|c|c|c|}
\hline $\begin{array}{c}\text { Current } \\
\text { density } / \\
\mathrm{A} / \mathrm{m}^{2}\end{array}$ & $\begin{array}{l}\text { Voltage } \\
\text { cell } / \mathrm{N}\end{array}$ & $\begin{array}{c}\text { Electrolysis } \\
\text { time } / \mathrm{min}\end{array}$ & $\begin{array}{c}\text { Fluoride residual } \\
\text { concentration / } \\
\text { ppm } \\
\end{array}$ & $\begin{array}{c}\text { Fluoride removal efficiency by } \\
\text { electrocoagulation } / \%\end{array}$ & $\begin{array}{c}\text { Overall fluoride } \\
\text { removal efficiency } \\
\% \%\end{array}$ \\
\hline \multirow{4}{*}{100} & \multirow{4}{*}{1.7} & 15 & 131.85 & 40.61 & 86.82 \\
\hline & & 30 & 110.71 & 50.13 & 88.93 \\
\hline & & 45 & 98.88 & 55.46 & 90.11 \\
\hline & & 60 & 75.50 & 65.99 & 92.45 \\
\hline \multirow{4}{*}{200} & \multirow{4}{*}{2.4} & 15 & 121.50 & 45.27 & 87.85 \\
\hline & & 30 & 89.71 & 59.59 & 91.03 \\
\hline & & 45 & 62.74 & 71.74 & 93.73 \\
\hline & & 60 & 59.27 & 73.30 & 94.07 \\
\hline \multirow{4}{*}{300} & \multirow{4}{*}{3.2} & 15 & 109.58 & 50.64 & 89.04 \\
\hline & & 30 & 57.34 & 74.17 & 94.27 \\
\hline & & 45 & 45.71 & 79.41 & 95.43 \\
\hline & & 60 & 51.10 & 76.98 & 94.89 \\
\hline
\end{tabular}

initial concentration: $222 \mathrm{ppm} \mathrm{F}^{*}, \mathrm{pH}_{\mathrm{mi}}=5.2$

TABLE 2

WORKING CONDITIONS, FLUORIDE RESIDUAL CONCENTRATION FOR EFL AND FLUORIDE REMOVAL EFFICIENCY

\begin{tabular}{|c|c|c|c|c|c|}
\hline $\begin{array}{l}\text { Current } \\
\text { density } / \\
\mathrm{A} / \mathrm{m}^{2}\end{array}$ & $\begin{array}{l}\text { Voltage } \\
\text { cell } / \mathrm{V}\end{array}$ & $\begin{array}{c}\text { Electrolysis } \\
\text { time / min }\end{array}$ & $\begin{array}{l}\text { Fluoride residual } \\
\text { concentration } / \\
\text { ppm }\end{array}$ & $\begin{array}{c}\text { Fluoride removal efficiency by } \\
\text { electrocoagulation } / \%\end{array}$ & $\begin{array}{c}\text { Overall fluoride } \\
\text { removal efficiency } \\
/ \%\end{array}$ \\
\hline \multirow{4}{*}{100} & \multirow{4}{*}{1.7} & 15 & 116.00 & 47.75 & 88.40 \\
\hline & & 30 & 82.56 & 62.81 & 91.74 \\
\hline & & 45 & 70.09 & 68.43 & 92.99 \\
\hline & & 60 & 63.56 & 71.37 & 93.64 \\
\hline \multirow{4}{*}{200} & \multirow{4}{*}{2.4} & 15 & 81.61 & 63.24 & 91.84 \\
\hline & & 30 & 66.91 & 69.86 & 93.31 \\
\hline & & 45 & 32.43 & 85.39 & 96.76 \\
\hline & & 60 & 37.01 & 83.33 & 96.30 \\
\hline \multirow{4}{*}{300} & \multirow{4}{*}{3.2} & 15 & 53.99 & 75.68 & 94.60 \\
\hline & & 30 & 50.68 & 77.17 & 94.93 \\
\hline & & 45 & 37.76 & 82.99 & 96.22 \\
\hline & & 60 & 41.96 & 81.10 & 95.80 \\
\hline
\end{tabular}

initial concentration: $222 \mathrm{ppm} \mathrm{F}^{*}, \mathrm{pH}_{\text {ini }}=6.2$

Table 3

WORKING CONDITIONS, FLUORIDE RESIDUAL CONCENTRATION FOR EFL AND FLUORIDE REMOVAL EFFICIENCY

\begin{tabular}{|c|c|c|c|c|c|}
\hline $\begin{array}{l}\text { Current } \\
\text { density } / \\
\mathrm{A} / \mathrm{m}^{2}\end{array}$ & $\begin{array}{l}\text { Voltage } \\
\text { cell } / \mathrm{V}\end{array}$ & $\begin{array}{l}\text { Electrolysis time } \\
\qquad / \mathrm{min}\end{array}$ & $\begin{array}{c}\text { Fluoride residual } \\
\text { concentration } / \\
\text { ppm }\end{array}$ & $\begin{array}{l}\text { Fluoride removal efficiency } \\
\text { by electrocoagulation /\% }\end{array}$ & $\begin{array}{c}\text { Overall fluoride } \\
\text { removal efficiency } \\
\% \%\end{array}$ \\
\hline \multirow{4}{*}{100} & \multirow{4}{*}{1.7} & 15 & 122.25 & 44.93 & 87.77 \\
\hline & & 30 & 86.75 & 60.92 & 91.32 \\
\hline & & 45 & 68.25 & 69.26 & 93.18 \\
\hline & & 60 & 60.70 & 72.66 & 93.93 \\
\hline \multirow{4}{*}{200} & \multirow{4}{*}{2.4} & 15 & 93.64 & 57.82 & 90.64 \\
\hline & & 30 & 91.11 & 58.96 & 90.89 \\
\hline & & 45 & 47.57 & 78.57 & 95.24 \\
\hline & & 60 & 70.06 & 68.44 & 92.99 \\
\hline \multirow{4}{*}{300} & \multirow{4}{*}{3.2} & 15 & 65.69 & 70.41 & 93.43 \\
\hline & & 30 & 48.26 & 78.26 & 95.17 \\
\hline & & 45 & 44.71 & 79.86 & 95.53 \\
\hline & & 60 & 45.42 & 79.54 & 95.46 \\
\hline
\end{tabular}

initial concentration: $222 \mathrm{ppm} \mathrm{F}^{-}, \mathrm{pH}_{\text {ini }}=7.2$

pH was 7.2 at electrolysis time of 15 and $45 \mathrm{~min}$, respectively, the fluoride removal efficiency increased as the applied current density increased, while at 30 and 60 min, respectively, the maximum of fluoride removal efficiency was obtained at $300 \mathrm{~A} / \mathrm{m}^{2}$.

The electrochemical reactions that occur at the electrodes during the electrocoagulation are (1) and (2), and in aqueous solution (3):

$$
\begin{array}{ll}
\text { anode }(+) & \mathrm{Al} \rightarrow \mathrm{Al}^{3+}+3 \mathrm{e}^{-} \\
\text {cathode }(-) & 2 \mathrm{H}_{2} \mathrm{O}+2 \mathrm{e}-\mathrm{H}_{2}+2 \mathrm{OH}^{-} \\
\text {aqueous solution } & \mathrm{Al}^{3+}+3 \mathrm{OH}^{-} \rightarrow \mathrm{Al}^{-}(\mathrm{OH})_{3}
\end{array}
$$

The mechanism of fluoride removal by electrocoagulation is not yet clear. According to Zhu et al. [21] at least three mechanisms may occur:

(i)adsorption on aluminium hydroxide particles

$$
\mathrm{Al}(\mathrm{OH})_{3}+\mathrm{xF}^{-} \rightarrow \mathrm{Al}(\mathrm{OH})_{3-\mathrm{F}^{2}}+\mathrm{xOH}^{-}
$$

(ii) coprecipitation

$\mathrm{nAl}+(3 \mathrm{n}-\mathrm{m}) \mathrm{OH}^{-}+\mathrm{mF}^{-} \rightarrow \mathrm{Al}_{\mathrm{n}} \mathrm{F}_{\mathrm{m}}(\mathrm{OH})_{3 \mathrm{n}-\mathrm{m}}$

(iii) fluoride attachment to electrodes

Regardless of the mechanism, the linear dependence of fluoride removal efficiency on electrolysis time or current density and its exceptions can be explained by Faraday's 
Law according to the amount of dissolved Al is directly proportional to the amount of electricity passing through the solution during electrocoagulation.

That is why the higher amount of electricity, the higher the amount of coagulant and the generated bubbles. Thus, byincreasing the current density, the formation rate of $\mathrm{Al}^{3+}$ and $\mathrm{OH}^{-}$ions will increase which will accelerate the process of pollutant removal. If the solution becomes excessively alkaline due to the formation of more $\mathrm{OH}^{-}$, the amount of $\mathrm{Al}(\mathrm{OH})_{3}$ decreases because it is well known that it is amphoteric and thus the amount of $F$ - removed decreases.

The specific energy consumption is an important parameter for the characterization of the fluoride removal process by electrocoagulation and was calculated according to equation (6) for operating parameter values that led to the best results of fluoride removal efficiency: pH of 6.2, applied current density of $200 \mathrm{~A} / \mathrm{m}^{2}$ and electrolysis time of 45 minutes. The volume of EFL was $500 \mathrm{ml}$. A value of $5.6 \mathrm{kWh} / \mathrm{m}^{3}$ was obtained.

where:

$$
\mathrm{Q}=\mathrm{U} \cdot \mathrm{I} \cdot \mathrm{t} \cdot 10^{-3} / \mathrm{V} \cdot 3600
$$

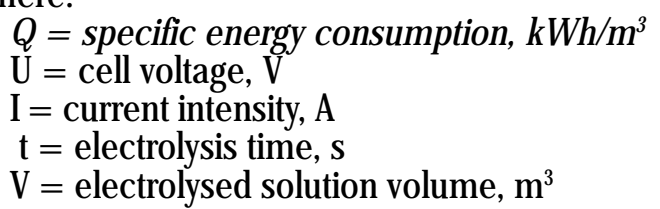

\section{Conclusions}

This study dealt with the removal of fluoride from industrial effluents by precipitation followed by electrocoagulation with Al as sacrificial anode. The combination of these processes proved to be effective for fluoride removal. Thus, fluoride concentration in the simulated industrial effluent was lowered from 1000 ppm to $222 \mathrm{ppm}$ by precipitation, and by electrocoagulation the removal fluoride efficiency was $85.39 \%$ that leaded to an overall fluoride removal efficiency of $96.76 \%$.

Acknowledgements: This work was carried out within the framework of a Nucleu Program, managed by The Romanian Ministry of Research and Innovation, project code PN 18050302.

\section{References}

1.TAFU, M., ARIOKA, Y., TAKAMATSU, S., TOSHIMA, T., Euro-Mediterr. J. Environ. Integr., 1, no. 1, 2016, article 4.

2.GOUIDER, M., FEKI, M., SAYADI, S., J. Hazard. Mater., 170, 2009, p. 962.

3.FEMINA CAROLIN, C., SENTHIL KUMAR, P., SARAVANAN, A., JANET JOSHIBA, G., NAUSHAD, MU., J. Environ. Chem. Eng., 5, 2017, p. 2782. 4.de LUNA, M.D.G., WARMADEWANTHI, LIU, J.C., Colloids Surf. A. Physicochem. Eng. Asp., 347, 2009, p. 64.

5.WAJIMA, T., UMETA, Y., NARITA, S., SUGAWARA, K., Desalination, 249, 2009, p. 323.

6.CAI, Q., TURNER, B.D., SHENG, D., SLOAN, S., J. Contam. Hydrol., 177-178, 2015, p. 136

7.ESKANDARPOUR, A., ONYANGO, M.S., OCHIENG, A., ASAI, S., J. Hazard. Mater., 152, 2008, p. 571.

8.ZHANG, Y., XU, Y., CUI, H., LIU, B., GAO, X., WANG, D., LIANG, P., J. Rare Earth, 32, no. 5, 2014, p. 458.

9.MEHTA, D., MAZUMDAR, S., SINGH, S.K., J. Water Process Eng., 7, 2015, p. 244.

10.LIU, Q., ZHANG, L., YANG, B., HUANG, R., Int. J. Biol. Macromol., 77, 2015, p. 15.

11.MANDAL, S., TRIPATHY, S., PADHI, T., SAHU, M.K., PATEL, R.K., J. Environ. Sci., 25, no. 5, 2013, p. 993.

12.HARJA, M., KOTOVA, O., CIOBANU, G., LITU, L., $20^{\text {th }}$ International Symposium on The Environment and the Industry, 2017, p. 69.

13.EL BOUTAYBI, B., DEDIU, V., COSMA, C., $20^{\text {th }}$ International Symposium on The Environment and the Industry, 2017, p. 85.

14.PINCOVSCHI, I., NEACSU, N., MODROGAN, C., Rev. Chim. (Bucharest), 68, no. 4, 2017, p. 635.

15.TEODORESCU, S., ION, R.M., NECHIFOR, G., BUCURICA, I.A., DULAMA, I. D., STIRBESCU, R.M., STIRBESCU, N.M., Rev. Chim. (Bucharest), 68, no. 4, 2017, 869.

16.MELIDIS, P., Environ. Process., 2, 2015, p. 205.

17.AOUDJ, S., DROUICHE, N., HECINI, M., OUSLIMANE, T., PALAOUANE, B., Procedia Engineer., 33, 2012, p. 111.

18.KHALEK, M.A.A., EL HOSINY, F.I., SELIM, K.A., OSAMA, I., Sustain. Water Resour. Manag., doi: 10.1007/s40899-017-0199-z

19.BAZRAFSHAN, E., MOHAMMADI, L., ANSARI-MOGHADDAM, A., MAHVI, A.H., J. Environ. Health. Sci., 13, no. 1, 2015, article 74.

20.IHOS, M., BOGATU, C., CRISTEA, I., MANEA, F., PODE, R., Rev. Chim. (Bucharest), 67, no. 8, 2016, p. 1462.

21.ZHU, J., ZHAO, H., NI, J., Sep. Purif. Technol., 56, 2007, p. 184.

Manuscript received: 12.08 .2018 